\title{
Affective Technologies in the Age of Creative Destruction
}

\author{
Jeffrey Mantz
}

As I read these chapters, I was reminded of Marx's perhaps most important intellectual contribution to understanding the socially transformative power of capitalism: in this modern historical epoch, it is not just things, but time itself (for Marx [1976]) it was our labour time) that becomes commodified. And what others (and objects) do with or to our time tends to bring out the most visceral of human responses. There is a whole subgenre of videos on YouTube featuring people destroying their mobile phones (see Rigg 2013). They drown them, roll over them with construction equipment, douse them in gasoline and set them on fire, pierce them with drills and, of course, microwave them. If affective identities can be expressed through consumption (Miller 1998) in subtle, lingering and disturbing ways, like accessorising your iPhone with colourful absurdities, then it is worth exploring whether the converse might be true. There is something cathartic about blasting the hell out of an object that you feel is tearing apart your being and sensibility. I wonder whether these video bloggers would find common cause and kinship with the masses who smashed all the clocks during the storming of the Bastille (see Benjamin 1968: 261-62). Since the first accountants became the valorised caretakers of modernity, we have been cursed with constantly having to know what time it is. Like many denizens of the new data generation, I have a watch that counts how many steps I take each day, what my average resting heart rate is and how well I have slept. How and when did I become such a numerical fetishist that I care about these totals? These truly are the handcuffs of modernity, and we seem to have fastened them of our own volition. 
As Robert Foster notes, 'The generation of surplus value is now and always has been a matter of time management - squeezing profit from every available moment'. That is now firmly entrenched in decision and management science, and the frontiers of efficiency seem to have no bounds. IBM is experimenting with tracking devices for cows in Tasmania to isolate what factors might contribute to optimal dairy production (such as allowing cows to determine the pace at which they are milked). Cowlar, a similar 'Fitbit for cows' technology, is being marketed by a Pakistanbased company.

So the innovation of mobile communications companies using top-up or pay-as-you-go services to capture consumers throughout the Global South is an expected outcome for industries that have to find new markets to survive and thrive. But the disciplining of consumptive behaviour through the use it or lose it phone credit agreements represents an innovative step in this new political economic chapter of market expansion.

We see it elsewhere, of course. Schüll (2012) describes Vegas as a giant machine oriented around extracting profit through its regimenting of time. Time's regimentation is entirely arbitrary and relative. The same processes that enable us to sit in front of a slot machine for 10 hours without the need for a catheter are arguably responsible for our lack of enough patience to watch a viral video clip that is more than six seconds long. As Golub (2004, 2010), Boellstorff $(2012,2015)$ and many others (e.g. Nardi 2010; Snodgrass et al. 2011) have noted, yes, our online avatars are political economic actors. But, while you can make money selling the things you build in online environments, how long do you have to invest in a massive multiplayer online game to do that?

It is not individual contracts or dollar amounts that matter so much as the habits that are produced and regimented. And new digital technologies have proven astonishingly good at regimenting humans. Elsewhere, I have called the ways that technology 'has subjected its users to forms of social disengagement and disembodiment', a kind of 'zombification' (Mantz 2013: 178). Like a zombie virus, technologies are contagious and depend on an erosion of sensory experience. To put it another way (paraphrasing Lauro and Embry 2008), the social composition of an undead-appearing horde depends on the social decomposition of the humans from which they cull their numbers. Mobile phones are in fact the perfect host for contagion because their very use and existence depends on the user 
infecting someone else with use. This is what Foster is calling 'temporal discipline', as something that not only encourages but also might 'actually enforce consumption'.

Of course, attempts at the political-economic disciplining of our lives can be met with creative resistance. The sending of free credit requests with coded amounts is an interesting case in point, just like the 'missed call' that pings someone else your location (that they need to call you or come downstairs and meet you, for example). And of course, capital adapts, with $11 \mathrm{pm}-7 \mathrm{am}$ talk time bundles incentivising use at low traffic times, but disciplining sleep (or lack thereof) in the process. As the boundaries between work and leisure are becoming blurred, and what we are calling leisure is turning into work, we have indeed seen an interesting shift from the workers that Thompson discussed, who felt pressure to give up all non-purposive activity. Non-purposive activity is becoming rapidly commodified in this context, and there is an interesting battle over temporality and regimentation of labour taking place. One wonders what Gluckman (1954) might have thought of these pay-as-you-go incentives. Are these the new rituals of rebellion?

We see some of this playing out in Daniela Kraemer's discussion of the reputational economy of mobile phone credits in Vanuatu. Here, mobile phone credits are viewed as an opportunity for young urban men to build relationships outside the kastom economy, from which they have been disenfranchised. Social networks are built through the accumulation and redistribution of mobile phone credits. There is no big phone credit moka (or other form of ritualised exchange one might find outside Papua New Guinea) at the end of this - it is much more individuated and decentralised - but reputation and prestige are valued in much the same way. As Kraemer notes, drawing on Horst and Miller's (2005) work, this is not about giving with the expectation of reciprocity; it's about the building of relationships and networks. Like the Gawan kula ceremonial system described by Munn (1992), credit sharing or the possession of credit, generates the kind of subjectivities that form the social relationships.

One cannot help wondering about issues of gender and class playing out in mobile credit gift economies in ways that they may not play out elsewhere in Vanuatu. The exchange between Toby and Rose is a case in point (Chapter 5). Rose's brother finds the exchange 'disrespectful' of women, while Toby fantasises about retaliating against Rose for stringing him along with the broken promise of a credit transfer. Kraemer asks 
whether 'teach[ing] her a lesson' is a way of reclaiming his 'masculine potency'. That observation reminds me of the debates about respectability in the island societies of the Caribbean (Besson 1993; Wilson 1973), home to an observably gendered moral and ethical system within which young men expend significant time and energy in building their reputation through any number of acts and investments (certain personal styles, becoming adept in conversation or in skills that draw attention to oneself). These acts and investments become more pronounced as young men are deprived in other economic areas, thus making 'reputation' the most reliable investment to which one should devote resources and time.

Anthropologists working in Caribbean and Oceanic societies have similarly described how vast amounts of time are devoted quite rationally in building non-monetary forms of capital, such as reputation or status. Toby invests here in something that did not represent much financially. But that is precisely the point: this is the form of capital that he can build. Caribbeanist scholars have asked whether these reputational investments are in fact rituals of rebellion. The Caribbean practices that are historically most associated with reputation (Calypso; mepwi-a skill that involves one becoming exceptionally adept at insulting others; and sexual conquest, or romantic banditry, if that sounds softer) are all 'skills' that are periodised: they reach a height during Carnival. Here in Vanuatu, we have an arguably 'non-purposive' activity that relies on the estrangement of male youth to facilitate the livelihood of mobile phone credits.

Dan Jorgensen's chapter (Chapter 3) deals with the rise of Digicel's market share dominance in the PNG mobile market, and what social transformations are implied as mobile phone towers begin to blot the landscape at exponential rates. Of course, there are social evils associated with mobile phones. The way they are described here (as associated with moral problems such as sexual impropriety, pornography and harassment) are evocative of the ways that technology has long served as a principle accelerant for immorality. TVs used to be the culprits. Then VCRs eliminated the stigma of having to walk shamefully into adult theatres. The media has changed, but the complexities of social relationships wrought by technological transformation have a long history. Freud (1959) interestingly wrote over 100 years ago about 'modern nervousness', a debilitating ailment of the industrial revolution, best treated through developmental freelisting on his office couch. One might understand this in the context of Papua New Guinea as a crisis of 'respectability' - moral quandaries emerge when the predictability of regimented social relations 
is thrown asunder. They can even be, as Jorgensen notes drawing on Bell's work, 'conduits for sorcery'. Here, those social evils are mediated. His informant Toby is quite different from Kraemer's Toby. His phone, while it also saved his life, was a vehicle to a different future, where he could get back to a more village-based life in which he and his wife could raise chickens for the PNG food industry. This is why the Chinese crewman story and the apocalyptic warnings to the youths who stole his laptop about the existence of an omnipresent, American-controlled 'mobile system' are so fascinating. Mobile technology for Toby and his ilk is marked by uncertainty. It is a different platform entirely, one that is apocalyptic but simultaneously responsible for saving his life. But he aspires to a future marked less by the oscillation between such radical antipodes, even if he has intimate late-night conversations (presumably with those abundant $11 \mathrm{pm}-7$ am talk minutes) with his phone friend. As the villager quoted in the final sentence of his chapter reminds us, 'With the mobile you can never escape - but then you can never get lost, either'.

In rural Sepik villages, mobile phones become devices that reinforce and expand kin relations and social responsibilities, in ways that are accelerated by the phone's inherent capacity to collapse time and space. David Lipset (Chapter 1) notes that initially in Papua New Guinea, attitudes toward mobile phones and the abundant towers were largely positive, reflecting a 'keen desire for connectivity' - remote areas 'explicitly asked to bring in towers'. This desire mirrored the scholarly response: mobile phones increased transparency and accountability and opened lines of communication, much like how some might appeal to the documentary accountability afforded through the installation of body cameras on police officers. The free and open flow of information will save us from ourselves. And there is sociality of course: not just relatives, but also the building of social ties over long distances.

What kind of new 'anonymous modernity' is being formed, which lacks mediation within the dyad of the two doing the communicating, and whose relationship is precarious precisely because it is not mediated (unless Toby's brother gets on Rose's phone, and the brother can remind him of the norms of respectability)? By way of analogy, is this initiation of 'autonomous relationships' responsible for, say, the romantic deserts that younger adults in the cosmopolitan centres of the Global North complain about? Is social media the 'tinder' box (to shamefully reference the social networking and mobile dating app) of enduring social commitments? Unlike urban settings marked already by social disaffection, in rural 
settings, as Venis reminds us, mobile phones are less about new terrains of sociality and more about reinforcing enduring social bonds and a sense of 'collective responsibility'. The phones of Darapap village reminded me of the single landline phone I found on the college dormitory floor in the 1980s. And, once individual phones were installed in rooms a year later, we all suddenly knew much less about each other. Anyone who happened upon a ringing phone had the responsibility to shepherd the call. Yes, the mobile phone of Darapap can expand the physical space of kinship; and the handset might be private property, but it is not an individualistic device. It may rein in the immoral self, the one that villagers say is engaged in duplicitous behaviour, or infidelity or witchcraft. One does wonder what kinds of calls Venis is shepherding. That phone fosters and reinforces relations beyond the community. As Lipset suggests with his closing sentence, the phone 'may also be associated with the maintenance of moral networks linking rural communities and places with their urban diasporas'.

Heather Horst's (Chapter 4) Fijian mobile phone users are contending with a market environment in which, unlike Papua New Guinea, where Digicel dominates, there is some semblance of competition between two mobile communication giants (Vodafone and Digicel, although a third provider, Vodafone subsidiary Inkk, has a small low-income market share). Horst asks whether the branding strategies deployed in these contexts amount to 'branding cultures', where the experience of buying the product is much more embodied. That's a fair question; we do sleep with our mobile phones after all (though one hesitates to concede too much to a philosophic perspective like that of Georg Simmel [1978], in which our principal form of cultural identification comes to be through the objects that we procure and present to others). My iPhone doesn't define me as a person, but it certainly disembodies a lot of information about me as a person. And all that data is certainly useful to companies that are attempting to profile particular brands and market a viable brand culture. Digicel actively works to develop a brand that can 'understand and "respect" diverse cultures', sponsoring concert venues with hip international stars. Sometimes it backfires when, for example, Sean Kingston or Shaggy says something misogynistic and the press catches wind of it. Their brand of strategic regionalisation seems to have to work harder than Vodafone, which has earned itself a reputation for fostering enduring Fijian futures and traditions, pensions and bati songs. 
Advertising is indeed often designed to be sentimental and affective in establishing brands, even for unlikely goods and services. American consumers can recall a series of sappy investment banking ads in the 1990s. Thailand now has a series of extended life insurance spots extolling the long-term returns on daily humanitarian investment (for example, an impoverished child whose life is transformed through the modest alms of a good-hearted if monastic benefactor) that are being virally circulated among sobbing global masses. Marketing houses are adept at cultivating sentimentality for some unusual products. But affective marketing doesn't necessarily translate into immediate consumer decisions. Branding is not always about sales; it's about establishing recognition. Coca-Cola certainly does not need to expand its market base in most parts of the world, but they do pay a fee to retain it (and associate it with something that creates an affective attachment, like a generalised reciprocity of soft drinks and smiles). I did wonder whether the highly nationalist approaches to branding was part of a strategy of skirting ethnic differences among Fijians. So Digicel is 'trying', while Vodafone does not have to, because they deal with common national investments like rugby (just as cricket or baseball or soccer become a unifying national force in other parts of the world; see, for example, James 1983). Thus, Horst's call for us to look more at mobile phones as mediated by spheres of consumers, companies and the state is essential to understanding how companies are branded.

Holly Wardlow's chapter (Chapter 2) explores mobile phones as an affective technology, which 'not only mediates the expression and experience of emotion, but also opens up new forms of emotional intimacy', against the backdrop of public health campaigns that view the mobile phone as merely a means of disciplining medication practices. Women with HIV in Tari, Papua New Guinea, use their mobile phones to recruit " $p$ phone friends" who may provide emotional comfort, mental diversion, romantic escapism and even material support'. Similar to what Jorgensen described in the case of Toby, these phone friends are essentially intimate strangers with whom one establishes a friendship through the phoning (and the recipient accepting) a random and unknown call. In exploring mobile phone use in this way, Wardlow resists the typical analytical tendency to treat the mobile phone as a biopolitical/biomedical instrument and instead repositions it as a tool for embodied and agentive practice among an otherwise stigmatised group of women. Its creative use against methods of regimentation and discipline (both at the state level and in other social and institutional organisational contexts) can be extrapolated to other 
research contexts. Rather than uniquely PNG phenomena, the mobile activities of these women would seem to be analogous to other practices where technology has been used to seek intimate social relationships anonymously. Can this practice be generalised to other practices where unencumbered social relationships are pursued precisely because of the constraints of kin or familial obligations? Social relationships often weigh heavily, particularly for marginalised individuals, and tend not to provide any kind of intimacy. I found it interesting (especially in the cases of Angela and Lucy) how God mediated discussions between phone friends. These conversations seem to function as a sort of testimonial or confession for those whose social order has failed them. If protracted conversations with mobile phone strangers seem on the surface to be a complete waste of time, maybe that is precisely the point: the phone friend provides the antidote to the temporal discipline inherent in other forms of social communication.

These chapters collectively help us to understand the temporal battles that are being waged throughout Oceanic societies as they engage new digital communications technologies. So much of what is discussed in this volume focuses on the how these technologies are embodied in human behaviour. I began my comments with an account of the visceral experiences recounted in the videos of people who delighted in smashing their mobile phones. I did so because we also must remember that human behaviour can become embodied in the physical technologies themselves. Our moral engagement with technologies and the actions that result from such engagement are unpredictable, challenging our ability to control them, lest they come to control us. Nobody is happy when they drop their mobile phone in the toilet. But it sure feels good to throw one on the ground.

\section{References}

Benjamin, W. 1968. Illuminations: Essays and Reflections. New York: Schocken Books.

Besson, J. 1993. Reputation and Respectability Reconsidered: A New Perspective on Afro-Caribbean Peasant Women. In Women and Change in the Caribbean, J.H. Momsen, ed. Indiana University Press, pp. 15-37. 
Boellstorff, T. 2012. Ethnography and Virtual Worlds: A Handbook of Method. Princeton University Press.

2015. Coming of Age in Second Life: An Anthropologist Explores the Virtually Human. Princeton University Press.

Freud, S. 1959 [1908]. Civilized Sexual Morality and Modern Nervous Illness. In The Standard Edition of the Complete Psychological Works of Sigmund Freud, vol. 9, J. Strachey, ed. London: Hogarth Press.

Gluckman, M. 1954. Rituals of Rebellion in South-East Africa. Manchester University Press.

Golub, A. 2004. Copyright and Taboo. Anthropological Quarterly 77(3): 521-30.

- 2010. Being in the World (of Warcraft): Raiding, Realism, and Knowledge Production in a Massively Multiplayer Online Game. Anthropological Quarterly 83(1): 17-45. doi.org/10.1353/anq.0.0110

Horst, H.A. \& D. Miller 2005. From Kinship to Link-up: Cell Phones and Social Networking in Jamaica. Current Anthropology 46(5): 75578. doi.org/10.1086/432650

James, C.L.R. 1983. Beyond a Boundary. Durham, NC: Duke University Press.

Lauro, S.J. \& K. Embry 2008. A Zombie Manifesto: The Nonhuman Condition in the Era of Advanced Capitalism. boundary 2, 35(1): 85-108. doi.org/10.1215/01903659-2007-027

Mantz, J.W. 2013. On the Frontlines of the Zombie War in the Congo: Digital Technology, the Trade in Conflicted Minerals, and Zombification. In Monstrous Cultures in the 21st Century: A Reader, M. Levina \& B.-M. Bui, eds. New York: Continuum Press, pp. 177-92.

Marx, K. 1976 [1867]. Capital: A Critique of Political Economy, Volume I. Ben Fowkes, trans. New York: Penguin Books.

Miller, D. 1998. A Theory of Shopping. Ithaca, NY: Cornell University Press. 
Munn, N.D. 1992. The Fame of Gawa: A Symbolic Study of Value Transformation in a Massim (Papua New Guinea) Society. Durham, NC: Duke University Press.

Nardi, B. 2010. My Life as a Night Elf Priest: An Anthropological Account of World of Warcraft. Ann Arbor, MI: University of Michigan Press.

Rigg, S. 2013. Comments to Performance and New Media Panel for Workshop, Unseen Connections in the Ecologies of Cell Phones, Smithsonian Institution, Washington, DC, 27 February-1 March.

Schüll, N.D. 2012. Addiction by Design: Machine Gambling in Las Vegas. Princeton University Press.

Simmel, G. 1978. The Philosophy of Money. Tom Bottomore and David Frisby, trans. London: Routledge \& Kegan Paul.

Snodgrass, J.G., M.G. Lacy, H.J. Francois Dengah \& J. Fagan 2011. Enhancing One Life Rather than Living Two: Playing MMOs with Offline Friends. Computers in Human Behavior, 27(3): 1211-22. doi. org/10.1016/j.chb.2011.01.001

Wilson, P.J. 1973. Crab Antics: The Social Anthropology of English-speaking Negro Societies of the Caribbean. New Haven, CT: Yale University Press. 
This text is taken from The Moral Economy of Mobile Phones: Pacific Islands Perspectives, edited by Robert J. Foster and Heather A. Horst, published 2018 by ANU Press, The Australian National University,

Canberra, Australia.

doi.org/10.22459/MEMP.05.2018.07 